\title{
FIRST RECORD OF PREDATION OF MICRURUS MIPARTITUS (SERPENTES: ELAPIDAE) ON OSCAECILIA POLYZONA (GYMNOPHIONA: CAECILIIDAE) IN COLOMBIA
}

\section{PRIMER REGISTRO DE DEPREDACIÓN DE MICRURUS MIPARTITUS (SERPENTES: ELAPIDAE) EN OSCAECILIA POLYZONA (GYMNOPHIONA: CAECILIIDAE) EN COLOMBIA}

\author{
Juan David FernándeZ-RoldáN 1,", Guido Fabian Medina-RangeL ${ }^{2,3}$ \& Yeny R. López-Perilla² \\ ${ }^{1}$ Laboratorio de Anfibios, Instituto de Ciencias Naturales, Universidad Nacional de Colombia, Bogotá, Colombia. \\ ${ }^{2}$ Grupo de Morfología y Ecología Evolutiva, Instituto de Ciencias Naturales, Universidad Nacional de Colombia, Bogotá, Colombia. \\ ${ }^{3}$ Grupo Biodiversidad y Conservación, Instituto de Ciencias Naturales, Universidad \\ Nacional de Colombia, Bogotá, Colombia. \\ Correspondence: : fernandezroldanjd@gmail.com \\ Received: 2021-01-07. Accepted: 2021-04-07.
}

Resumen.- Las cecilias y las serpientes de coral son animales evasivos que rara vez se encuentran durante el trabajo de campo de un herpetólogo. Es bien sabido que estas serpientes se alimentan de otros vertebrados vermiformes como las lagartijas amphisbaenidas, cecilias y otras serpientes que pueden o no, ser de su misma especie. Por el contrario, las cecilias presentan un mayor vacío de información sobre su dieta y demás aspectos de historia natural ya que sus hábitos fosoriales impiden acceder a esta información. Reportamos el primer registro de Micrurus mipartitus depredando a Oscaecilia polyzona, uno de los caeciliidos menos conocidos del país, esto en base a una fotografía tomada en Cimitarra, Santander, Colombia. Esta foto nos permite incluir a O. polyzona dentro de la dieta de M. mipartitus.

Palabras clave.- Cecilias, Comportamiento, Dieta, Elápidos, Historia Natural, Serpientes de Coral.

Abstract.- Caecilians and coral snakes are evasive animals that are rarely encountered by herpetologists during their fieldwork. Coral snakes are well known to prey on other vermiform vertebrates such as amphisbaenid lizards, caecilians and other snakes which may or may not be conspecific to them. On the contrary, the information void regarding caecilian diet composition is even greater because their fossorial habits keep their natural history a secret. We here provide the first register of Micrurus mipartitus feeding on Oscaecilia polyzona, one of the least known caeciliids in the country, based on a photograph taken in Cimitarra municipality, Santander department, Colombia. This photograph allows us to claim O. polyzona as a new prey item in the diet of M. mipartitus.

Keywords.- Behavior, Caecilians, Coral snakes, Diet, Elapids, Natural history.

Oscaecilia polyzona (Fischer, 1880) is among Colombia's least known caeciliids. This species inhabits the Magdalena Valley lowlands with records in Antioquia, Caldas, Cesar, Córdoba, Cundinamarca, Tolima, and Santander departments, ranging from 150-810 m.a.s.l. (Lynch, 2000). This species can be diagnosed from the other sympatric Gymnophiona of the Magdalena Valley chiefly because its eyes are concealed under bone (Taylor, 1968), and by its range of 192-217 primary grooves, 12-42 secondary grooves, length/width 43-69 times and its mainly pink/purple coloration in life (Lynch, 2000; Lynch \& Acosta, 2004). Although Lynch and Acosta (2004) considered it to be abundant in La Dorada municipality, Caldas department, the species has not been so regularly encountered elsewhere and the newest records are casual and isolated. This is most likely linked to the secretive fossorial life of most caecilians, which makes finding these animals a very challenging endeavor. Not surprisingly most natural history aspects (i.e., reproduction, diet, behavior and habitat preferences) remain largely unknown for most caecilian species.

Micrurus mipartitus (Duméril, Bibron \& Duméril, 1854) is a widely distributed venomous snake found in Brazil (Rondônia), Colombia, Costa Rica (southeast), Ecuador, Panama and Venezuela (west) (Uetz et al., 2021). In Colombia, it inhabits 


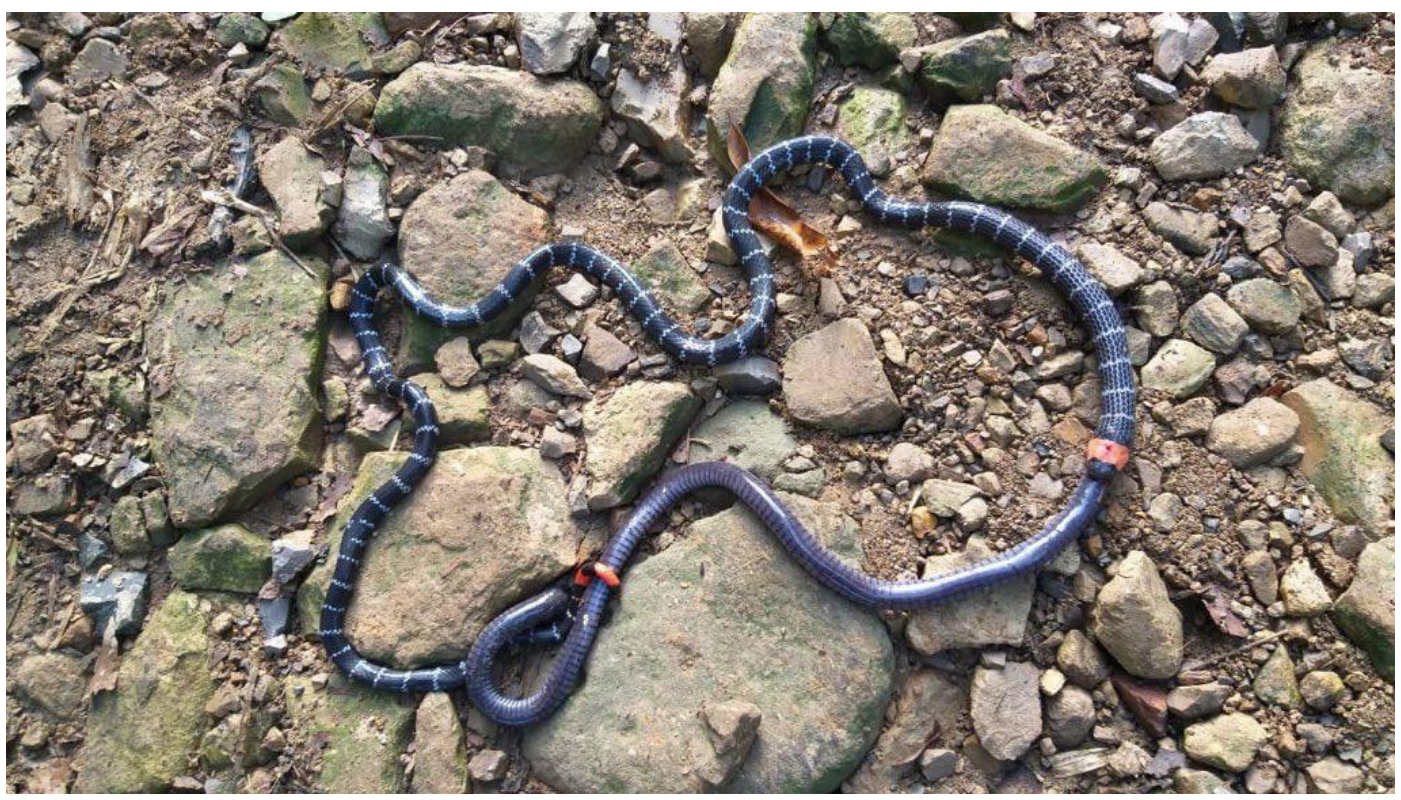

Figura 1. Micrurus mipartitus depredando a Oscaecilia polyzona en la localidad de Campo Opon, vereda La Verde, municipio de Cimitarra, departamento de Santander, Colombia. Nótese que la coral se comió a la cecilia desde la cabeza. Fotografía de Julio César Martínez Ortega.

Figure 1. Micrurus mipartitus preying on Oscaecilia polyzona in Campo Opon locality, vereda La Verde, Cimitarra municipality, Santander department, Colombia. Notice the coral snake ate the caecilian head-first. Photograph by Julio Cesar Martinez Ortega.

the Magdalena and Cauca Valley lowlands, but also the Pacific and Caribbean plains, and the Orinoquía region, ranging from 0-2700 m.a.s.l. (Rios-Soto et al., 2018). This species has a particular coloration pattern that consists of a main black body with 45-84 complete white or yellow bands and with a bright red-orange parietal ring on the head and 2-5 red/orange bands on the tail; Its body is very slender and its total length ranges from 500-1406 mm (Vera et al., 2019); Ventral scales 254-284 in males and 279-326 in females, and subcaudal scales (usually divided) 26-35 in males and 23-31 in females (Campbell \& Lamar 2004; Rodríguez-Guerra, 2019). Individuals with yellow bands occur in western Colombia and those with white ones in eastern Colombia (Ayerbe et al., 1990; Rios-Soto et al., 2018). Captive individuals of $M$. mipartitus are known to prey on Caecilia occidentalis, Pholidobolus vertebralis, Atractus gr. iridescens, A. lehmanni, Dendrophidion vivittatus, Erythrolamprus epinephelus and Sibon nebulatus (Vera-Pérez et al., 2019), whilst A. manizalesensis (Rodríguez-García \& Díaz-Ayala, 2015) and Bachia bicolor (VeraPérez et al., 2019) are known to be preyed upon in situ.

This coral snake is known to prey on caecilians, as do most other Micrurus (Greene, 1973; 1984; Roze, 1996: 57; Marques \& Sazima, 1997), but the identity of their prey is usually not confirmed, which is unfortunate. The use of the term 'caecilian' generates ambiguity, given that Caecilia guntheri Dunn, 1942,
C. pulchraserrana Acosta-Galvis, Torres \& Pulido-Santacruz, 2019, C. subnigricans Dunn, 1942, C. thompsoni Boulenger, 1902, Microcaecilia nicefori (Barbour, 1924), M. pricei (Dunn, 1944), O. polyzona and Typhlonectes natans (Fischer, 1880), are all found in the Magdalena Valley of Colombia. Moreover, not all species simply live underground, some are fully aquatic (e.g., T. natans), some live under leaf litter (e.g., C. thompsoni, C. subnigricans and M. nicefori) and some live within organic matter in soft, moist soils (C. pulchraserrana and O. polyzona).

In February 2020, amidst the dry season, Engineer Julio Cesar Martinez Ortega observed - unbeknownst to him - a coral snake feeding on a caecilian in Campo Opon (Fig. 1), vereda La Verde, Cimitarra municipality, Santander department, Colombia, $\left(6.384361^{\circ} \mathrm{N}, 73.882753^{\circ} \mathrm{W}, 170 \mathrm{~m}\right.$ a.s.l.; Fig. 2), during the evening hours (14:00-16:00 hrs). The engineer contacted us seeking an identification for the animals that he had photographed because he was (understandably) uncertain of what he had witnessed during his routine fieldwork (Fig. 1). The photograph clearly depicts a $M$. mipartitus coral snake feeding on a caecilian. The identity of the Amphibian would prove more challenging to establish, given that the total count of primary grooves was impossible to determine because the animal had already been eaten head-first and the first fifth of the total length was now inside the coral snake. 


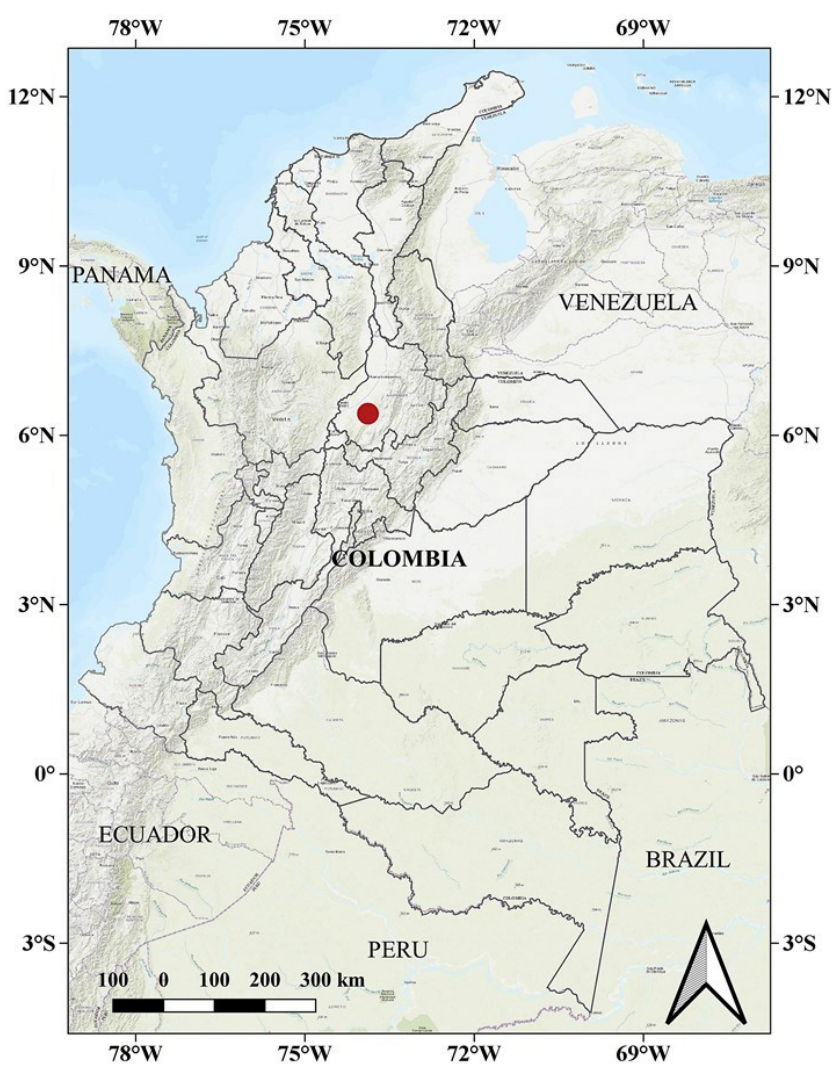

Figura 2. Mapa de Colombia mostrando la localidad del registro fotográfico (punto rojo) de Micrurus mipartitus alimentándose de Oscaecilia polyzona en la localidad de Campo Opon vereda La Verde, municipio de Cimitarra, departamento de Santander, Colombia.

Figure 2. Map of Colombia showing the locality of the photographic register (red dot) of Micrurus mipartitus feeding on Oscaecilia polyzona in Campo Opon locality, vereda La Verde, Cimitarra municipality, Santander department, Colombia.

Aided by a HD television screen, we noted that the attacked caeciliid was O. polyzona, due to counts of secondary grooves ( $\mathrm{n}=$ 20) and bright purple body coloration (as can be seen in Lynch \& Acosta 2004:588, Fig. 4 in there). This record constitutes the first predation case on O. polyzona by M. mipartitus and is one of the very few existing records on this genus of caecilians apart from that of Villacampa \& Whitworth (2016) for O. bassleri and more recently that of Escalante \& Amador (2020) for O. osae. Although there is still much left unknown about the biology and natural history of O. polyzona, registering the predators of the species enriches the current knowledge about its ecology, and allows us to affirm that both genera of the family Caeciliidae (i.e., Caecilia and Oscaecilia) suffer attacks primarily from snakes with fossorial habits. These predator-prey dynamics can be facilitated due to the fossorial lifestyle that brings both animals to the same environment.

Acknowledgements. - We thank Julio Cesar Martinez Ortega for sharing his excellent photograph and informing us of the event that he was able to observe during his fieldwork in Santander. Juan Carlos Sánchez-Nivicela and Sebastian Duarte Marín made very valuable comments and suggestions to the manuscript and we thank them for their input. Professors John D. Lynch at Instituto de Ciencias Naturales, Universidad Nacional de Colombia, Bogotá, Juan Manuel Daza at Universidad de Antioquia, Medellín, Julio Mario Hoyos at Universidad Javeriana, Bogotá, Manuel Bernal at Universidad del Tolima, Ibagué, and Martha Patricia Ramirez at Universidad Industrial de Santander, Bucaramanga, allowed us to examine the available specimens of M. mipartitus and O. polyzona under their care.

\section{CITED LITERATURE}

Ayerbe, S., M.A. Tidwell, \& M. Tidwell. 1990. Observaciones sobre la biología y comportamiento de la serpiente coral "rabo de ají" (Micrurus mipartitus). Descripción de una subespecie nueva. Novedades Colombianas, Museo de Historia Natural, Universidad del Cauca, Popayán 2:30-41.

Campbell, J.A. \& W.W. Lamar. 2004. The venomous reptiles of the western hemisphere. Cornell University Press, Ithaca, NY. Comstock Publishing, Cornell University Press, Ithaca.

Escalante, R.N. \& H.S. Amador. 2020. The Osa Caecilian (Oscaecilia osae): New localities, elevational record, and predation by a Common Black-Hawk (Buteogallus anthracinus). Reptiles \& Amphibians 27:491-493.

Greene, H.W. 1973. Defensive tail display by snakes and amphisbaenians. Journal of Herpetology 7:143-161.

Greene, H.W. 1984. Feeding behavior and diet of the eastern coral snake, Micrurus fulvius. Special publication / University of Kansas, Museum of Natural History 10:147-162.

Lynch, J.D. 2000. Una aproximación a las culebras ciegas de Colombia (Amphibia: Gymnophiona). Revista de la Academia Colombiana de Ciencias Exactas, Físicas y Naturales 23 (suplemento especial):317-337.

Lynch, J.D. \& A.R. Acosta. 2004. Discovery of Oscaecilia polyzona (Amphibia:Gymnophiona:Caeciliaidae) in the Middle Magdalena 
with notes on its abundance and habitat. Revista de la Academia Colombiana de Ciencias Exactas, Físicas y Naturales 28:585-589.

Marqués, O.A.V. \& I. Sazima. 1997. Diet and feeding behavior of the coral snake, Micrurus corallinus, from the Atlantic forestof Brazil. Herpetological Natural History 5:88-93.

Rios-Soto, J.A, J. Arango-Lozano \& F.A. Rivera Molina. 2018. Micrurus mipartitus (Duméril, Bibron y Duméril, 1854). Catálogo de Anfibios y Reptiles de Colombia 4:37-44.

Rodríguez-García, C. \& R.F. Díaz-Ayala. 2015. Micrurus mipartitus (Red-tailed coral Snake, coral rabo de ají). Diet/ophiophagy. Herpetological Review 46:275.

Rodríguez-Guerra, A. 2019. Micrurus mipartitus En: Torres-Carvajal O, G. Pazmiño-Otamendi \& D. Salazar-Valenzuela. 2019. Reptiles del Ecuador. Versión 2019.0. Museo de Zoología, Pontificia Universidad Católica del Ecuador. https://bioweb.bio/faunaweb/ reptiliaweb/FichaEspecie/Micrurus\%2omipartitus, accessed in December 2020.
Roze, J.A. 1996. Coral Snakes of the Americas: Biology, Identification, and Venoms. Krieger Publishing Company. Malabar, Florida, U.S.A.

Uetz, P., P. Freed \& J. Hošek (eds.). 2021. The Reptile Database, http://www.reptile-database.org, accessed in February 2021.

Vera-Pérez, L.E., J.A. Zuñiga-Baos \& S. Ayerbe González. 2019. Nuevos registros de longitud y dieta de Micrurus mipartitus (Duméril, Bibron \& Duméril, 1854) (Serpentes: Elapidae). Novedades Colombianas 4:49-56.

Villacampa, J. \& A. Whitworth. 2016. Predation of Oscaecilia bassleri (Gymnophiona:Caecilidae) by Anilius scytale (Serpentes:Aniliidae) in southeast Peru. Cuadernos de herpetología 30:29-30.

Taylor, E.H. 1968. The Caecilians of the World. A Taxonomic Review. University of Kansas Press. 